\title{
PRE-GRADUATE PREPARATION OF FUTURE TEACHERS FOR INCLUSIVE EDUCATION AND WORKING WITH PUPILS WITH SPECIAL EDUCATIONAL NEEDS
}

\author{
[PREGRADUALNA PRIPRAVA BUDUCICH UCITELOV PRE \\ INKLUZIVNE VZDELAVANIA A PRE PRACU SO ZIAKMI SO \\ SPECIÁLNYMI VYCHOVNOVZDELAVACIMI POTREBAMI]
}

\section{Zuzana Osvaldova - Veronika Vrabcova}

doi: 10.18355/PG.2020.9.1.5

\begin{abstract}
The study focuses on information sheets of courses included in the pedagogical-psychological and social science study core (hereinafter common study core), dealing with the issue of inclusive education and preparation for working with pupils with special educational needs. The analysis of information sheets of teaching courses at individual faculties in Slovakia, which provide teacher training in the area of public higher education, was carried out via using the content analysis method. We found out that the common core consists of 366 courses, while the issue of inclusive education and pupils with special educational needs is addressed in 38 courses. The majority of these courses is offered at the master level of university study. Their preferred teaching method is a lecture. The issue of inclusive education is dealt with in compulsory optional subjects. In terms of content and scope dedicated to this issue, we divided the courses into two groups: courses which are fully dedicated to it and courses that deal with it only partially.
\end{abstract}

\section{Key words}

pupils' special educational needs, inclusive education, undergraduate education, student of teacher training program, course information sheet

\begin{abstract}
Abstrakt
Objektom štúdie sú informačné listy predmetov spoločného pedagogickopsychologického a sociálno-vedného základu (d’alej spoločný základ), venujúce sa problematike inkluzívneho vzdelávania a príprave pre prúcu so žiakmi so špeciálnymi výchovnovzdelávacími potrebami. Analýza informačných listov vyučovacích predmetov jednotlivých fakúlt na Slovensku, ktoré poskytujú v priestore verejného vysokého školstva učitel'skú prípravu, bola realizovaná prostredníctvom metódy obsahovej analýzy. Zistili sme, že spoločný základ je tvorený 366 vyučovacími predmetmi, pričom problematike inkluzívneho vzdelávania a žiakov so špeciálnymi výchovnovzdelávacími potrebami sa venuje 38 vyučovacích predmetov. Prevaha predmetov je v 2. stupni VŠ a preferovanou metódou výučby je prednáška. Predmetná problematika je nosne riešená v povinne volitel'ných predmetoch. Z hl'adiska obsahu sme predmety rozdelili do dvoch skupín: predmety, ktoré venujú problematike celú svoju obsahovú
\end{abstract}


a rozsahovú kapacitu a predmety, ktoré venujú problematike len čast' svojej obsahovej a rozsahovej kapacity.

\section{Kl’účové slová}

Špeciálne výchovnovzdelávacie potreby žiakov, inkluzívne vzdelávanie, pregraduálna príprava, študent učitel'stva, informačné listy predmetov

\section{Úvod}

Školy od nepamäti navštevujú žiaci a viac ako v minulosti sa v školách stretávame so žiakmi, ktorí sa od seba odlišujú nielen farbou pleti, ale d'alšími rôznymi špecifikami ich zdravotného stavu, prostredia z ktorého pochádzajú ako aj výnimočnými schopnost’ami. Ide o žiakov so špeciálnymi výchovnovzdelávacími potrebami (d’alej ŠVVP), ktorých zohl'adnenie má zabezpečit' rovnocenný prístup k vzdelávaniu, primeraný rozvoj schopností, osobnosti, ako aj dosiahnutie primeraného stupňa vzdelania a primeraného začlenenia do spoločnosti. (ŠVP ISCED 2, s. 14) V súvislosti s uvedeným sa čoraz viac používa pojem inkluzívne vzdelávanie.

Vláda Slovenskej republiky dňa 6. júna 2018 schválila Národný program rozvoja výchovy a vzdelávania na Slovensku. Jedným zo základných prvkov zmien v školstve má byt' zvýšenie inkluzívnosti v systéme. Súčasný stav inkluzívneho vzdelávania v podmienkach slovenského školstva podrobne popisuje Národný program rozvoja výchovy a vzdelávania Učiace sa Slovensko (Bratislava, 2017). Súčasný vzdelávací systém neumožňuje vytvárat' $v$ školách flexibilné vzdelávacie prostredie, ktoré by bez problémov dokázalo absorbovat' väčší počet žiakov so špeciálnymi výchovno-vzdelávacími potrebami (d’alej žiak so ŠVVP) v rámci individuálnej integrácie. $\mathrm{Na}$ stanovovanie inkluzívnych ciel’ov nie sú spravidla pripravení na Slovensku ani učitelia, ani zriad'ovatelia škôl a ani očakávania zo strany rezortu školstva neboli doposial' takto formulované. Pre zmenu vyššie uvedeného, príslušné orgány navrhli celý rad opatrení, ktoré majú tento stav zmenit'.

Inkluzívna škola je zamýšl’aná pre všetky deti, ochotná a schopná prijat' a pracovat' so žiakmi na plnom rozvoji ich potenciálu. Aby vízie zmien neboli len intuitívne, je potrebné venovat' pozornost' nielen učitel'om v školách, ale aj tým, ktorí sa na svoju učitel'skú profesiu pripravujú. Ako je zdôraznené v národnom programe Učiace sa Slovensko, súčast'ou inkluzívnej školy je učitel' ako podporovatel' na individuálny úspech orientovanej vzdelávacej kultúry s primeranými a zároveň vysokými očakávaniami na každého žiaka. Takýto učitel' je vybavený kompetenciami a zručnost'ami potrebnými k rozsiahlej individualizácii. Z uvedeného vyplýva, že pregraduálna príprava budúcich učitel'ov by mala byt' cielene zameraná aj na nadobudnutie vedomostí a zručností o práci so žiakmi so špeciálnymi výchovnovzdelávacími potrebami.

\section{Prierez dokumentov}

Oblast' inklúzie je aktuálnou problematikou rezortu školstva aj v medzinárodnom meradle. Jednotlivé krajiny ju akceptujú a ponímajú rôzne. 
Pojem inkluzívne vzdelávanie nie je $\mathrm{v}$ slovenskej legislatíve samostatne definovaný. Pracovná skupina pre inkluzívne vzdelávanie Rady vlády SR pre l'udské práva, národnostné menšiny a rodovú rovnost' zo 14. 06. 2011 v bode 4 pri definícii pojmu inkluzívne vzdelávanie vychádzala $\mathrm{z}$ príslušných dokumentov UNESCO (Policy Guidelines on the Inclusion in Education, 2009), Rady Európy a Európskej agentúry pre rozvoj špeciálneho vzdelávania (Bratislava, 2018). Za významnú podmienku pri realizácii inkluzívnej výchovy a vzdelávania $\mathrm{v}$ školách o. i. je považovaná kvalitná pregraduálnu prípravu študentov učitel'stva. Táto problematika má svoju teoretickú a empirickú rovinu na širokej národnej a medzinárodnej úrovni. Príprava budúcich učitel'ov $\mathrm{k}$ inkluzívnemu vzdelávaniu je predmetom mnohých štúdií, napr. Jodi L. Peebles, Preparing Teachers for Inclusive Classrooms: Introducing the Individual Direct Experience Approach, 2014, Kaleja, Zezulková, Preparedness of Czech Primary School Teachers for Inclusive Primary Education, 2018, Diana Rogers-Adkinson, Daryl Fridley, Preparing Teachers for Inclusive Education, 2016, Ilnar F. Yarullin, Ramis R. Nasibullov, Service teachers' preparedness for inclusive education, 2018, Christopher Boyle, Australian Pre-service Teacher Attitudes to inclusive education, 2017, Belková, Zólyomiová, 2015, Poláková, Spálová, 2015 a i.

V roku 2014 slovenské vysoké školy a univerzity prešli procesom komplexnej akreditácie. Naformulovali sa také vzdelávacie štandardy v informačných listoch (kritérium KSP-B2; MŠ SR, 2013), ktoré sú v súlade s výsledkami vzdelávania podl'a Európskeho kvalifikačného rámca (EKR, 2009) a následne nadväzujú na Národný kvalifikačný rámec Slovenskej republiky (NKR SR, MŠ SR, 2012). Výsledky vzdelávania vymedzujú, čo vzdelávaný vie a je schopný robit' po ukončení VŠ štúdia (ECTS, 2009).

Jednou $\mathrm{z}$ dôležitých častí systému kvality vysokoškolského vzdelávania je informačný list študijného predmetu. Model informačného listu predmetu je legislatívne viazaný na Vyhlášku č. 614/2002 Ministerstva školstva SR o kreditovom systéme štúdia (2013). Informačný list predstavuje oficiálny kurikulárny dokument, ktorý je všeobecne záväzný a prístupný vyučujúcemu a učiacemu sa. V informačnom liste je premietnutý vzdelávací štandard, čo je stanovená norma, ktorou sa formuluje súbor požiadaviek na študentov, ktoré by mali splnit' v určitých ročníkoch (Bajtoš, 2013).

Príprava budúcich učitel'ov $\mathrm{k}$ inkluzívnemu vzdelávaniu skúmaná prostredníctvom analýzy informačných listov predmetov je predmetom záujmom domácich i zahraničných štúdií. Autori M. López Torrijo a S. Mengual-Andres v príspevku s názvom „An Attack on Inclusive Education in Secondary Education. Limitations in Initial Teacher Training in Spain“" (2015) analyzovali počet a obsah predmetov venovaných inkluzívnemu vzdelávaniu na univerzitách pripravujúcich učitel’ov v celom Španielsku. Štúdia dospela $\mathrm{k}$ záveru, že táto počiatočná príprava učitel'ov poskytuje dostatočný teoretický základ týkajúci sa konceptualizácie inkluzívneho vzdelávania.

Juliana Cavalcante de Andrade Louzada a Claudia Regina Mosca Giroto v článku s názvom ,Teacher training according to the perspective of inclusive education in Brazil" (2015) analyzovali disciplíny, ktoré sa zaoberajú inkluzívnou edukáciou vo vzdelávaní budúcich učitel’ov. Autori 
vyhl'adávali dáta $\mathrm{v}$ odboroch humanitných, biologických a exaktných vied na troch verejných brazílskych univerzitách, ktoré poskytujú učitel'ské vzdelávanie. Výsledky ukázali väčšiu prítomnost' disciplín súvisiacich $\mathrm{s}$ inkluzívnym vzdelávaním $\mathrm{v}$ humanitných vedách, najmä na univerzite $\mathrm{v}$ Lengua Brasileña de Señales.

Bansal v článku Teacher Education Programmes Preparing Teachers for Inclusive Classrooms: A North India Context (2016), reflektuje programy vzdelávania budúcich učitel’ov na prácu v inkluzívných triedach. Pomocou metódy obsahovej analýzy preskúmal kurikulum pre inkluzívne vzdelávanie učitel'ov na trinástich univerzitách $\mathrm{v}$ severnej časti Indie. Z kurikula pre inkluzívne vzdelávanie vybral komponenty ako názov predmetu, charakter, rok, semester, v ktorom sa predmet vyučuje, body pridelené predmetu (kredity) a aktivity: teoretického alebo praktického zamerania. Zistil, že inkluzívne vzdelávanie na niektorých univerzitách nie je povinný predmet a na niektorých úplne absentuje. Predmety, ktoré sa obsahovo venujú inkluzívnemu vzdelávaniu sú založené na teoretických poznatkoch a chýba prepojenie s budovaním praktických zručností. Kredity pridelené za absolvovaný predmet obsahovo venujúci sa inkluzívnemu vzdelávaniu sú na niektorých univerzitách len polovičné, ako na ostatných. Autor v závere vyjadruje požiadavku zjednotenia, zaradenia povinných inkluzívnych predmetov, zameraných viac na praktickú čast' do pregraduálnej prípravy učitel'ov na všetkých univerzitách v severnej Indii.

V podmienkach slovenských vysokých škôl sa tejto problematike venovali Belková, Zólyomiová (2015), ktoré skúmali pregraduálnu prípravu učitel'ov na Katedre pedagogiky PF UMB v Banskej Bystrici vo vybraných predmetoch zameraných na prácu so žiakmi so ŠVVP. Štúdia prináša pohl'ad na úpravu študijných programov za posledných dvadsat' rokov v odbore učitel'stvo pedagogiky a zaradením disciplíny špeciálna pedagogika, integrovaná výchova a d’alších predmetov do týchto študijných programov.

Podobné zistenia prinášajú aj Poláková, Spálová (2017). Podl’a nich sa v pregraduálnej príprave študentov učitel'stva venuje málo pozornosti problematike l'udských práv, ktorých dodržiavanie je základným predpokladom spolužitia $\mathrm{v}$ multikultúrnom prostredí. V povinnom obsahu všeobecného základu prípravy študentov učitel'stva absentujú predmety, ktoré by učitel’ov pripravovali na výkon profesie $\mathrm{v}$ prostredí inkluzívnej školy. Ak sa tam takéto predmety aj vyskytujú, sú zväčša zaradené do kategórie volitel'ných predmetov.

Od učitel’a nižšieho sekundárneho stupňa sa požaduje vysokoškolské vzdelanie druhého stupňa $\mathrm{v}$ študijnom odbore učitel'stvo a pedagogické vedy. (Vyhláška č. 1/2020Z.z.) Požadovanú oblast' a rozsah vedomostí, zručností a kompetencií absolventa druhého stupňa vysokoškolského štúdia v odbore učitel'stvo a pedagogické vedy špecifikuje Vyhláška č. 244/2019 Z.z. O sústave študijných odborov. Výber uvádzame v tabul'ke 1.

Tabul'ka 1

\begin{tabular}{|l|c|c|}
\hline $\begin{array}{l}\text { Vedomosti } \\
\text { Zručnosti } \\
\text { Kompetencie }\end{array}$ & $\begin{array}{c}\text { Absolvent } \text { učitel'ských študijných programov disponuje: } \\
\text { rozvinutými poznatkami o biologických, } \\
\text { psychologických a sociálnych aspektoch vývinu }\end{array}$ \\
\hline
\end{tabular}

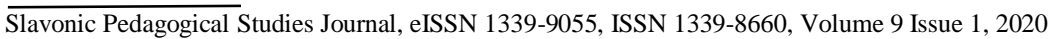


jednotlivca,

- pozná a chápe koncept inštitucionálneho socializačného procesu v širších sociálnovedných súvislostiach,

- má komplexný prehl'ad $\mathrm{v}$ sociálnej štruktúre spoločnosti,

- ovláda problematiku pedagogickej práce $\mathrm{v}$ kontexte diverzity vzdelávanej populácie,

- disponuje rozsiahlymi poznatkami o odlišnostiach vývinu jednotlivcov vyplývajúcimi z ich zdravotných alebo sociálnych znevýhodnení, alebo nadania a talentu tak, aby dokázal pri realizácii výchovno-vzdelávacieho procesu $\mathrm{v}$ podmienkach inkluzívneho vzdelávania efektívne kooperovat' so špeciálnymi pedagógmi, psychológmi a d'alšími odborníkmi a riadit' sa ich odbornými odporúčaniami a závermi,

- pozná aktuálne štátne vzdelávacie programy, ovláda teoretické základy projektovania, realizácie a hodnotenia výchovy a vzdelávania,

- ovláda rozsiahle teoretické a praktické súvislosti obsahu vzdelávania a odborovej didaktiky,

- disponuje rozsiahlymi psychologickými a didaktickými vedomostami umožňujúcimi porozumiet' vzt'ahu medzi procesmi učenia a vyučovania, vzdelávania a výchovy jednotlivca i dynamike sociálnej skupiny,

- pozná široký repertoár vyučovacích stratégií a metód

- orientuje sa v systéme výchovy a vzdelávania, v právnych predpisoch a kurikulárnych kontextoch výkonu učitel'skej profesie,

- pozná štruktúru profesie, profesijné zázemie odboru a princípy profesijnej etiky,

- pozná metodologické súvislosti empirického výskumu v pedagogických vedách,

- identifikuje vývinové a individuálne charakteristiky a individuálne vzdelávacie potreby jednotlivca,

- akceptuje individualitu žiaka,

- má praktické skúsenosti s identifikáciou psychologických a sociálnych faktorov učenia sa jednotlivca,

- akceptuje diverzitu žiakov v sociokultúrnom kontexte.

- dokáže samostatne hodnotit' rôznorodé pedagogické situácie a procesy, flexibilne na ne 
reagovat'.

Spracované podl'a:

https://www.zakonypreludi.sk/disk/zz/file/2019/2019c000z0244p001.pdf

2020.02.07 11.30

\section{Ciel' štúdie a metodológia}

Hlavným ciel'om štúdie bolo zistit', či v rámci predmetov tzv. spoločného základu sú zastúpené vyučovacie predmety, ktoré zameriavajú svoj obsah na prípravu a pôsobenie budúcich učitel'ov v inkluzívnych školách a na prácu so žiakmi so špeciálnymi výchovnovzdelávacími potrebami. $\mathrm{Na}$ zist'ovanie sme použili obsahovú analýzu dokumentov - informačných listov vyučovacích predmetov v 1. a 2. stupni VŠ, v rámci spoločného základu. Analýze boli podrobené informačné listy verejných vysokých škôl a univerzít. Pre získanie prístupu k informačným listom všetkých vysokých škôl a univerzít poskytujúcich učitel'ské vzdelávanie sme využili akademické informačné systémy AIS, MAIS - najmä ich verejné prístupy; kolegov a kolegyne jednotlivých vysokých škôl, ktorí nám prístup do tohto systému sprostredkovali.

Výskumný súbor tvorilo 366 informačných listov povinných, povinne volitel'ných a výberových predmetov spoločného základu, v ktorých sme hladali súvis s inkluzívnym vzdelávaním a s prácou so žiakmi so ŠVVP prostredníctvom súboru pojmov, ktoré sme pre potreby výskumu určili sami. Identifikovali sme 38 informačných listov. Pri metóde obsahovej analýzy sme sa opierali o poznatky Švec (1998), Gavora (2015), Dvořáková (2010). Základnou analytickou jednotkou bol celý text dokumentu.

Pred analýzou informačných listov sme si stanovili na základe naštudovanej problematiky súbor pojmov, ktoré majú súvis s problematikou inkluzívneho vzdelávania, špeciálnej pedagogiky, integrovanej výchovy, multikultúrnej výchovy. Identifikovali sme nasledovné: špeciálna a inkluzívna pedagogika, multikultúrna výchova, špeciálnopedagogické diagnostikovanie, pedagogické a výchovné poradenstvo, integratívna pedagogika, ŠVVP, kompetencie pro-inkluzívneho učitel'a, inkluzívna didaktika, inkluzívna škola, rodové rozdiely, práca s nadanými žiakmi, poruchy učenia, poruchy správania, špecifiká národnostných menšín, rodová diskriminácia, porušovanie práv, výchovný poradca, krízové situácie v triede, výchovné t’ažkosti, empatický prístup ku žiakovi, problémový žiak, výchova k slobode, výchova k demokracii, rasová znášanlivost', výchova $\mathrm{k}$ prosociálnosti, zát'ažové situácie $\mathrm{v}$ triede, rodová rovnost', rodovo citlivá výchova, poruchy detského vývinu, individuálne rozdiely žiakov, individuálny výchovno-vzdelávací program, sociálne a kultúrne nerovnosti v škole, špecifické edukačné postupy v práci so žiakmi so ŠVVP.

$\mathrm{Na}$ základe stanoveného ciel'a štúdie sme stanovili nasledovné výskumné otázky: 1. V ktorom stupni vysokoškolského štúdia je venovaná pozornost' predmetnej problematike vzdelávania? 2. Ktoré predmety, z hl'adiska charakteru povinný $(\mathrm{P})$, povinne volitel'ný (PV) a výberový (V) venujú pozornost' danej problematike vzdelávania? 3. Aká je forma výučby prednáška (P) seminár (S), cvičenie (C) a časová dotácia jednotlivých vyučovacích predmetov, venujúcich pozornost' predmetnej problematike? 4 
Aké je obsahové nasýtenie jednotlivých predmetov problematikou danou problematikou vzdelávania?

\section{Zistenia}

Učitel'ské vzdelanie na verejných vysokých školách v Slovenskej republike poskytujú pedagogické fakulty, filozofické, humanitné a prírodovedecké fakulty.

$\mathrm{K}$ jednej z dôležitých častí systému kvality vysokoškolského vzdelávania patrí informačný list študijného predmetu (ILP). V odbornej literatúre $\mathrm{k}$ nemu nachádzame málo informácíi. Vzor informačného listu predmetu je legislatívne viazaný na Vyhlášku Ministerstva školstva o kreditovom systéme štúdia (2013). Informačný list predstavuje všeobecne záväzný dokument. Ide o oficiálny kurikulárny dokument, v ktorom by sa mal premietnut' vzdelávací štandard. Ako uvádza vo svoje štúdii Kosturková, Průcha, Turek, Bajtoš sa zhodujú na tom, že vzdelávacie štandardy sú stanovené normy, ktoré formulujú požadovaný stupeň či úroveň edukačných procesov alebo ich výsledkov. Ide o súbor požiadaviek na študentov, ktoré by mali splnit' v určitých ročníkoch. Obsahový štandard vymedzuje učivo, výkonový štandard vymedzuje, čo si má študent $v$ danom predmete osvojit' (Bajtoš, 2013). Uvedené štandardy sú $\mathrm{v}$ informačných listoch zastúpené ako: 1. stručná osnova predmetu (uvádzajú sa témy, resp. obsahové zameranie predmetu), 2. výsledky vzdelávania (uvádzajú sa hlavné vzdelávacie výstupy, ktoré študent získava absolvovaním predmetu, a opis toho, čo by mal študent vediet', čomu

42 by mal rozumiet' a čo by mal byt' schopný robit' po úspešnom ukončení procesu vzdelávania).

V roku 2014 sa realizovala komplexná akreditácia vysokých škôl na Slovensku. Jej priebeh bol poznačený mnohými nie vždy jasnými a zrozumitel'nými pokynmi a krokmi, čo sa odzrkadlilo na konečnej podobe jednotlivých informačných listov predmetov. Napriek vyššie uvedenému, nie všetky informačné listy, ktoré sme mali $\mathrm{k}$ dispozícii boli vypracované v súlade s pokynmi uvedenými vo vyhláške o kreditovom systéme štúdia. (2013)

V tabul'ke 2 uvádzame jednotlivé vyučovacie predmety, ktoré sme na základe stanoveného súboru pojmov identifikovali ako tie, ktoré sa obsahovo dotýkajú problematiky inkluzívneho vzdelávania a práce so žiakmi so špeciálnymi výchovnovzdelávacími problémami. Ďalej tabul'ka obsahuje informácie o charaktere predmetu; počte kreditov získaných za predmet; forme výučby; rozsahu - hodinovej dotácii v priebehu semestra. Aj napriek jednotnému predpisu formy informačného listu podl'a príslušnej vyhlášky (2013), nie všetky informačné listy boli spracované v súlade s daným vzorom ILP. Preto nás zaujímalo, čo aj $\mathrm{v}$ tabul'ke $\mathrm{v}$ posledných dvoch stípcoch uvádzame, či je v ILP rozpracovaný obsahový štandard do konkrétnych tém a či výkonový štandard, resp. výsledky vzdelávania sú rozpracované na jednotlivých definovaných úrovniach, t.j. 1. vediet', 2. rozumiet', 3. byt' schopný urobit'. $Z$ viacerých taxonómií ciel'ov legislatívou definované úrovne výsledkov vzdelávania, ktoré majú študenti dosiahnut', nám bola najbližšia taxonómia podla belgického pedagóga J.H. de Blocka, ktorý navrhol štyri stupne: 1. znalost', vedomost'; 2. porozumenie; 3. aplikácia; 4. integrácia. 
V tabul'ke 2 v stĺpci výkonový štandard uvádzame: č. 1 - ak IPL má uvedené výsledky na úrovni vediet', č. 2 - ak ILP má uvedené výsledky na úrovni rozumiet'; č. 3 - ak ILP má uvedené výsledky byt' schopný urobit', t.j. aplikovat', integrovat'. Zohl'adňovali sme v jednotlivých stupňoch činnostné slovesá podl'a vyššie uvedenej taxonómie. Ako uvádzame vyššie, nie všetky informačné listy s ktorými sme pracovali boli spracované podla predpisu. V stĺpci obsahový štandard je uvedeným znakom vyjadrené, či ILP obsahuje obsahové zameranie predmetu prostredníctvom vymedzenia konkrétnych tém. Počet tém nebol vo všetkých ILP rovnaký, pohyboval sa v počte 8 až 20 . Daný stĺpec vyjadruje počet tém predmetnej problematiky z celkového počtu tém vyučovacieho predmetu.

Naším ciel'om nie je kriticky hodnotit' aktuálny stav výučby na vysokých školách, ale zmapovat' či sa v aktuálnej učitel'skej príprave, najmä v spoločnom základe takéto predmety nachádzajú. Z tohto dôvodu neuvádzame názvy jednotlivých VŠ, univerzít a fakúlt. Používame kódovanie: vel'ké rímske písmo - označenie VŠ alebo univerzity; číslo označenie fakulty. Názvy vyučovacích predmetov sme ponechali.

Tabul'ka 2

\begin{tabular}{|c|c|c|c|c|c|c|c|c|c|}
\hline 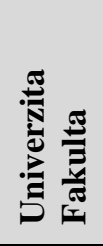 & 舜 & $\begin{array}{l}\text { Vyučovacie } \\
\text { predmety }\end{array}$ & 预 & 苞 & 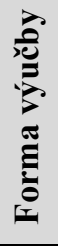 & 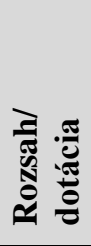 & 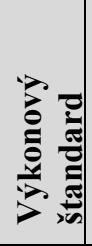 & 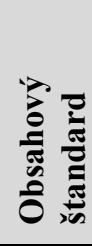 & $\begin{array}{l}\text { Sýtenos } \\
\text { t' } \\
\text { obsahu } \\
\text { danou } \\
\text { tematik } \\
\text { ou }\end{array}$ \\
\hline \multirow[t]{3}{*}{ A 1} & & Pedagogika 4 & $\mathrm{P}$ & 3 & $\mathrm{P}$ & $2 / 0$ & $\begin{array}{l}1,2, \\
3\end{array}$ & $\checkmark$ & $\begin{array}{l}100 \\
\%\end{array}$ \\
\hline & & $\begin{array}{l}\text { Edukácia } \\
\text { rómskych } \\
\text { žiakov }\end{array}$ & $\mathrm{V}$ & 1 & $\mathrm{P}$ & $1 / 0$ & \multicolumn{3}{|c|}{ neuvedené } \\
\hline & 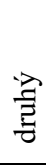 & $\begin{array}{l}\text { Poruchy } \\
\text { psychického } \\
\text { vývinu detí a } \\
\text { mládeže }\end{array}$ & $\mathrm{V}$ & 1 & $\mathrm{P}$ & $1 / 0$ & 1,3 & $\checkmark$ & $\begin{array}{l}100 \\
\%\end{array}$ \\
\hline $\begin{array}{l}\text { B } \\
1 \\
\text { B }\end{array}$ & $\overrightarrow{2}$ & $\begin{array}{l}\text { Psychický } \\
\text { vývin diet'at'a }\end{array}$ & $\mathrm{P}$ & 4 & $\begin{array}{l}\mathrm{P} / \\
\mathrm{S}\end{array}$ & $2 / 1$ & 1 & $\checkmark$ & $\begin{array}{l}\text { 1téma z } \\
12\end{array}$ \\
\hline 2 & $\stackrel{\vec{E}}{\vec{E}}$ & \multicolumn{8}{|c|}{$\begin{array}{l}\text { V učebnom pláne pedagogicko-psychologického a sociálno- } \\
\text { vedného základu v Mgr. stupni nie sú predmety, ktoré svoju } \\
\text { pozornost'venujú predmetnej problematike. }\end{array}$} \\
\hline
\end{tabular}




\begin{tabular}{|c|c|c|c|c|c|c|c|c|c|}
\hline \multirow{5}{*}{$\begin{array}{l}2 \\
\mathrm{C} \\
3\end{array}$} & \multirow[b]{2}{*}{ 党 } & \multicolumn{8}{|c|}{ Univerzita neposkytuje v Bc. stupňa učitel'ské zameranie } \\
\hline & & \\
\hline & \multirow[b]{3}{*}{ 拝 } & $\begin{array}{l}\text { Základy } \\
\text { špeciálnej } \\
\text { pedagogiky }\end{array}$ & $\mathrm{P}$ & 2 & $\mathrm{P}$ & $2 / 0$ & 1 & $\checkmark$ & $\begin{array}{l}100 \\
\%\end{array}$ \\
\hline & & $\begin{array}{l}\text { Výchovné } \\
\text { poradenstvo }\end{array}$ & $\begin{array}{l}\mathrm{P} \\
\mathrm{V}\end{array}$ & 2 & $\mathrm{C}$ & $0 / 2$ & 1 & $\checkmark$ & $\begin{array}{l}1 \text { téma } \mathrm{z} \\
12\end{array}$ \\
\hline & & $\begin{array}{l}\text { Psychológia } \\
\text { tvorivosti } \\
\text { a práca } \\
\text { s nadanými } \\
\text { v práci } \\
\text { učitel'a }\end{array}$ & $\begin{array}{l}\mathrm{P} \\
\mathrm{V}\end{array}$ & 2 & $\mathrm{C}$ & $0 / 2$ & 1 & $\checkmark$ & $\begin{array}{l}3 \text { témy } z \\
10\end{array}$ \\
\hline $\begin{array}{l}\text { D } \\
2 \\
\text { D }\end{array}$ & 空 & \multicolumn{8}{|c|}{$\begin{array}{l}\text { V učebnom pláne pedagogicko-psychologického a sociálno- } \\
\text { vedného základu v Bc. stupni nie sú predmety, ktoré svoju } \\
\text { pozornost' venujú predmetnej problematike. }\end{array}$} \\
\hline \multirow[t]{4}{*}{4} & \multirow[b]{4}{*}{$\vec{E}$} & $\begin{array}{l}\text { Pedagogická } \\
\text { psychológia }\end{array}$ & $\mathrm{P}$ & 3 & $\begin{array}{l}\mathrm{P} / \\
\mathrm{S}\end{array}$ & $1 / 1$ & $\begin{array}{l}1,2, \\
3\end{array}$ & $\checkmark$ & $\begin{array}{l}2 \text { témy } z \\
11\end{array}$ \\
\hline & & $\begin{array}{l}\text { Sociálno- } \\
\text { kultúrne } \\
\text { aspekty } \\
\text { edukácie }\end{array}$ & $\bar{P}$ & 3 & $\begin{array}{l}\mathrm{P} / \\
\mathrm{S}\end{array}$ & $1 / 1$ & $\begin{array}{c}1,2, \\
3\end{array}$ & $\checkmark$ & $\begin{array}{l}4 \text { témy z } \\
11\end{array}$ \\
\hline & & $\begin{array}{l}\text { Poruchy } \\
\text { psychického } \\
\text { vývinu }\end{array}$ & $\begin{array}{l}\mathrm{P} \\
\mathrm{V}\end{array}$ & 2 & $P$ & $1 / 0$ & $\begin{array}{c}1,2, \\
3\end{array}$ & $\checkmark$ & $\begin{array}{l}4 \text { témy } \mathrm{z} \\
12\end{array}$ \\
\hline & & $\begin{array}{l}\text { Učitel'ská } \\
\text { etika }\end{array}$ & $\begin{array}{l}\mathrm{P} \\
\mathrm{V}\end{array}$ & 2 & $\mathrm{P}$ & $1 / 0$ & $\begin{array}{c}1,2, \\
3\end{array}$ & $\checkmark$ & $\begin{array}{l}1 \text { téma } \mathrm{z} \\
8\end{array}$ \\
\hline \multirow[t]{6}{*}{ E 2} & \multirow[b]{4}{*}{ 胥 } & $\begin{array}{l}\text { Výchovné } \\
\text { poradenstvo }\end{array}$ & $\begin{array}{l}\mathrm{P} \\
\mathrm{V}\end{array}$ & 2 & $\mathrm{~S}$ & $0 / 1$ & 1 & $\checkmark$ & $\begin{array}{l}3 \text { témy z } \\
12\end{array}$ \\
\hline & & $\begin{array}{l}\text { Výchovné } \\
\text { problémy } \\
\text { v škole }\end{array}$ & $\mathrm{V}$ & 2 & $\mathrm{P}$ & $1 / 0$ & 3 & $\checkmark$ & $\begin{array}{l}100 \\
\%\end{array}$ \\
\hline & & $\begin{array}{l}\text { Práca } \\
\text { triedneho } \\
\text { učitel'a }\end{array}$ & $\begin{array}{l}\mathrm{P} \\
\mathrm{V}\end{array}$ & 2 & $\mathrm{~S}$ & $0 / 2$ & 1,3 & $\checkmark$ & $\begin{array}{l}2 \text { témy } z \\
12\end{array}$ \\
\hline & & $\begin{array}{l}\text { Výcvik } \\
\text { empatie }\end{array}$ & $\mathrm{V}$ & 1 & $\mathrm{C}$ & $0 / 1$ & 1,3 & $\checkmark$ & $\begin{array}{l}100 \\
\%\end{array}$ \\
\hline & \multirow[b]{2}{*}{ 舫 } & $\begin{array}{l}\text { Špeciálna } \\
\text { pedagogika }\end{array}$ & $\mathrm{P}$ & 2 & $\mathrm{P}$ & $1 / 0$ & $\begin{array}{c}1,2, \\
3\end{array}$ & $\checkmark$ & $\begin{array}{l}100 \\
\%\end{array}$ \\
\hline & & $\begin{array}{l}\text { Metódy } \\
\text { práce } \quad \mathrm{s} \\
\text { problémový }\end{array}$ & $\begin{array}{l}\mathrm{P} \\
\mathrm{V}\end{array}$ & 2 & $\mathrm{~S}$ & $0 / 1$ & 3 & $\checkmark$ & $\begin{array}{l}100 \\
\%\end{array}$ \\
\hline
\end{tabular}




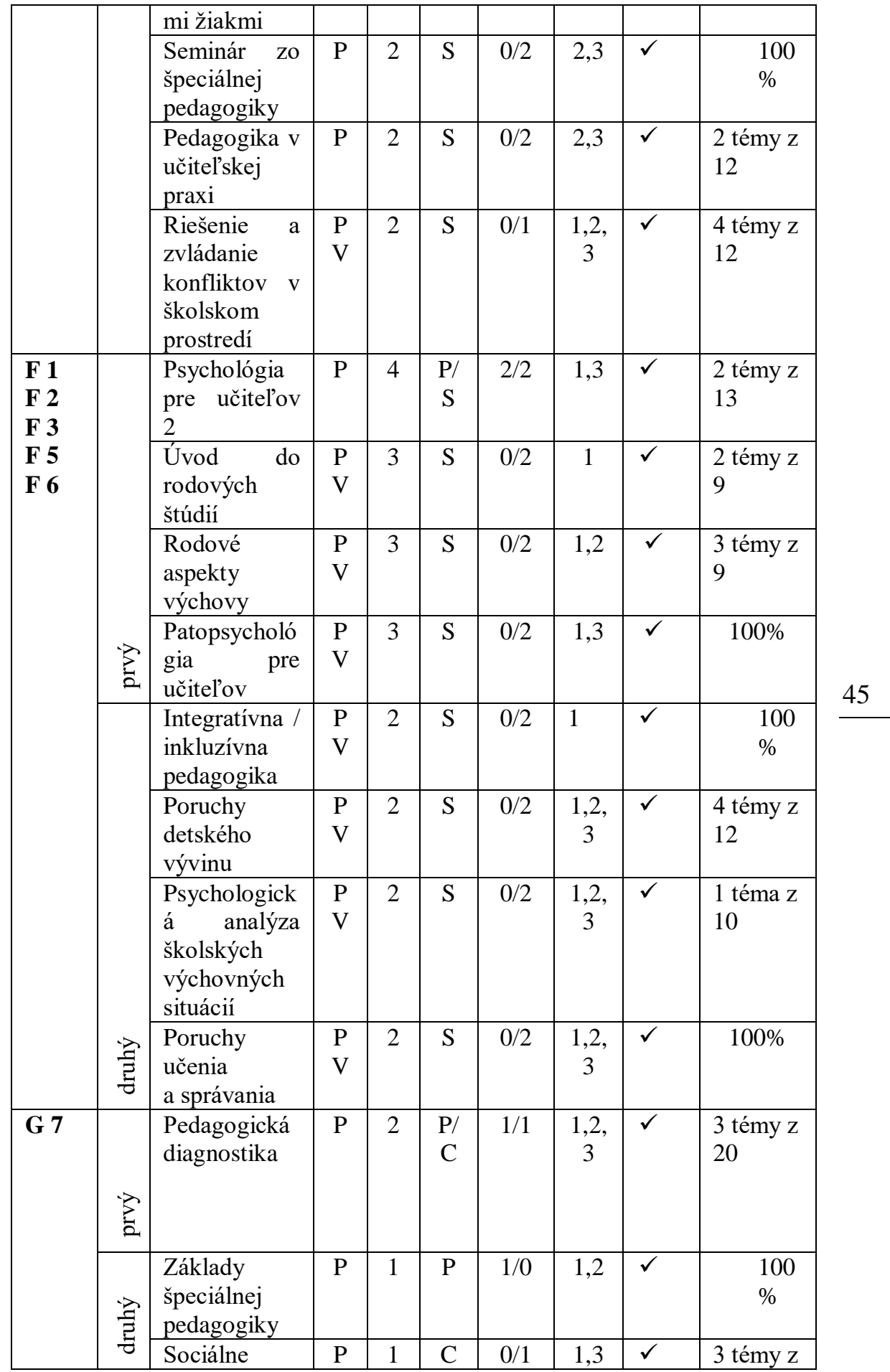




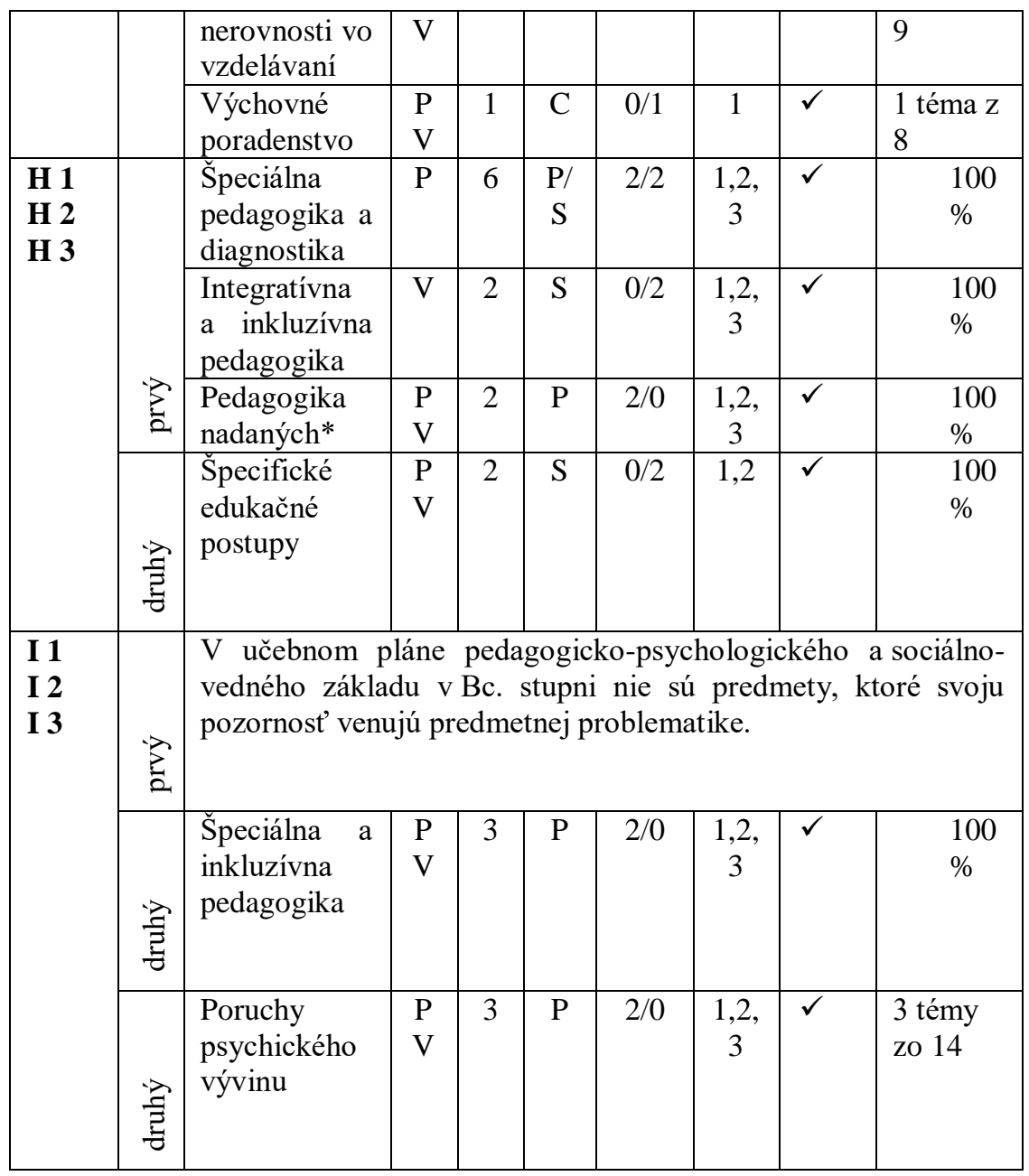

Zdroj: vlastné spracovanie *Predmet Pedagogika nadaných tvorí Spoločný pedagogicko-psychologický a sociálno-vedný základ učitel'stva pre PG.

\section{Diskusia}

Obsahovou analýzou tridsiatich ôsmich informačných listov vyučovacích predmetov tzv. spoločného základu sme zistili, že pomer predmetov venujúcich sa problematike inkluzívneho vzdelávania a práci so žiakmi so ŠVVP v prvom a druhom stupni vysokoškolského štúdia je $\mathrm{v}$ prospech druhého stupňa štúdia. Dôvodov prečo v procese prípravy akreditácie študijných odborov a programov jednotlivé vysoké školy volili takýto princíp sýtenia stupňov štúdia predmetmi môže byt' viacero. Domnievame sa, že rozhodujúcim faktorom boli požiadavky na kvalifikačné predpoklady pedagogických zamestnancov, podla ktorých sa od učitel'a vyžaduje ukončený druhý stupňa VŠ štúdia. Ako je uvedené v tabul'ke 2, dve $\mathrm{z}$ deviatich vysokých škôl $\mathrm{v}$ rámci prvého stupňa $\mathrm{VŠ} \mathrm{v}$ učebnom pláne spoločného základu neobsahujú predmety, ktoré venujú pozornost' v rámci 
obsahu inkluzívnemu vzdelávaniu a práci so žiakmi so špeciálnymi výchovnovzdelávacími potrebami. Jedna univerzita neposkytuje $\mathrm{v}$ učebnom pláne spoločného základu predmety s predmetnou problematikou $\mathrm{v}$ druhom stupni vysokoškolského štúdia a jedna univerzita $\mathrm{z}$ daného počtu vysokých škôl v prvom stupni neposkytuje učitel'ské štúdium vôbec.

Profil jednotlivých študijných programov je tvorený predmetmi povinnými, povinne volitel’nými a výberovými. Zistili sme, že z počtu 38 predmetov venujúcich pozornost' problematike práce so žiakmi so ŠVVP a inkluzívnemu vzdelávaniu je 12 predmetov povinného charakteru, 21 povinne volitel'ného charakteru a 5 výberového charakteru. Povinne volitel'né a výberové predmety majú vel'ký význam, nakol'ko si ich študent / študentka volia vo vzt’ahu k vlastným preferenciám - profilácie, naplneniu požiadaviek akreditačného spisu o minimálnom počte povinne volitel'ných a výberových predmetov a v neposlednom rade aj ako prostriedok dosiahnutia potrebného počtu kreditov $\mathrm{v}$ jednotlivých stupňoch štúdia. Tieto predmety však nesú to riziko, že si ich študenti do svojho zápisného listu nezapíšu, alebo v prípade jeho neúspešného ukončenia ho môžu nahradit' iným predmetom. Čo môže viest' $\mathrm{k}$ tomu, že predmety, ktoré sa venujú predmetnej problematike síce $\mathrm{v}$ ponuke sú, ale v danom akademickom roku sa ich výučba realizovat' nemusí. Preto vysoký počet povinne volitel'ných a výberových predmetov hodnotíme skôr negatívne zhl'adiska všeobecnej prípravy na učitel'ské povolanie.

Vysokoškolské vzdelávanie sa realizuje rôznymi metódami. $\mathrm{V}$ učitel'skej príprave $\mathrm{k}$ tradičným metódam patria prednášky, semináre, praxe, ale stretávame sa aj s cvičeniami, tréningami, kurzami. Síce ide o metódy, ktoré majú hlbokú tradíciu vo vysokoškolskom vzdelávaní, zmeny, inovácie sa dotkli aj ich. Na základe uvedených údajov $\mathrm{v}$ informačných listoch predmetov sme zistili, že 26 vyučovacích predmetov je organizovaných aj ako semináre a cvičenia, čím predpokladáme, že študenti sú aktívne zapájaní do procesu výučby. Zvyšných 18 vyučovacích predmetov je realizovaných prostredníctvom prednášok. Celkový počet je vyšší ako samotný počet vyučovacích predmetov a to $\mathrm{z}$ dôvodu, že niektoré vyučovacie predmety majú kombinovanú metódu výučby $\mathrm{P} / \mathrm{S}$ ( 5 predmetov) alebo $\mathrm{P} / \mathrm{C}$ (1 predmet). Najpreferovanejšou metódu výučby je prednáška. Toto zistenie vôbec nehodnotíme ako negatívny jav. Pri tvorbe akreditačných spisov Ministerstvo školstva, vedy, výskumu a športu SR vydalo odporúčania $\mathrm{k}$ tvorbe samotných spisov, $\mathrm{v}$ ktorých sa odporúča realizovat' prednášky interaktívnym spôsobom, t.j. zapojením samotných študentov do procesu výučby napr. pripravením si podnetov, otázok pre vyučujúceho, naštudovaním stanovených textov, statí $\mathrm{k}$ problematike a pod. Prednášky podl'a týchto odporúčaní nemajú byt' len monológom vyučujúceho. Berúc do úvahy tieto odporúčania sa domnievame, že aj prednáška ako metóda výučby je pre študentov $\mathrm{v}$ ich príprave rovnako prínosná ako seminár alebo cvičenie.

Dôležitým údajom $\mathrm{v}$ informačných listoch boli obsahy / osnovy jednotlivých predmetov. Z počtu všetkých vyučovacích predmetov venujúcich sa inkluzívnemu vzdelávaniu a príprave študentov na prácu so žiakmi so ŠVVP sme identifikovali 18, ktoré predmetnej problematike 
venujú celú svoju obsahovú a rozsahovú kapacitu. Ide o predmety, ktoré nesú názov: Pedagogika 4, Výchovné poradenstvo, Výchovné problémy v škole, Špeciálna pedagogika (Základy špeciálnej pedagogiky, Seminár zo špeciálnej pedagogiky, Špeciálna pedagogika a diagnostika, Špeciálna a inkluzívna pedagogika), Metódy práce s problémovými žiakmi, Patopsychológia pre učitel'ov, Integratívna / inkluzívna pedagogika, Poruchy detského vývinu, Poruchy učenia a správania, Pedagogika nadaných, Poruchy psychického vývinu. Zvyšné predmety (20) sme akceptovali v príprave k inkluzívnemu vzdelávaniu a práci so žiakmi so ŠVVP, nakol'ko čast' ich obsahu je nevyhnutná pre študentov učitel'ských študijných programov $\mathrm{k}$ identifikácii normy, subnormy a nadnormy vývinu žiaka.

Povinnou súčast’ou ILP sú „,výsledky vzdelávania“, v ktorých sa definujú hlavné vzdelávacie výstupy, ktoré študent získava absolvovaním predmetu, a opis toho, čo by mal študent vediet', čomu by mal rozumiet' a čo by mal byt' schopný robit' po úspešnom ukončení procesu vzdelávania. V tejto súčasti analyzovaných ILP sme zaznamenali vel'ké rozdiely v kvalite spracovania. V niektorých ILP sme sa stretli len s vel'mi všeobecným uvedením toho, čo sa od študenta požaduje a bolo vel'mi t'ažké v nich identifikovat' vo vzt'ahu k uvedenej taxonómii, na akej úrovni rozvíja daný predmet vedomosti, zručnosti, kompetencie študentov. Tiež sme sa stretli s nekompabilitou medzi obsahovým zameraním a výsledkami vzdelávania, v ktorých sa neodrážali všetky témy tvoriace obsah predmetu. Vel'mi často sme identifikovali, že čast' výsledky vzdelávania nebola spracovaná v pohl'ade na študenta, ale v pohl'ade na samotného vyučujúceho daného vyučovacieho predmetu. Pomenované boli činnosti učitel'a a nie výsledky študenta. Šestnást’ ILP v časti ,výsledky vzdelávania“ bolo spracovaných so zretel'om na všetky tri úrovne: vediet', rozumiet', byt' schopný.

Na základe analýzy jednotlivých ILP (v časti obsahové zameranie) môžeme konštatovat', že pregraduálna príprava nie je zameraná na pôsobenie budúcich učitel'ov $\mathrm{v}$ inkluzívnej škole, ale jadrovo je zameraná na integratívnu výchovu a vzdelávanie žiakov. Uvedomujeme si, že učitel'ské vzdelávanie nie je tvorené len predmetmi tzv. spoločného základu, ale aj predmetmi jednotlivých študijných - predmetových kombinácií, ktorých učebné plány môžu kompenzovat’ tieto nedostatky spoločného základu. Táto oblast' nebola ale predmetom nášho zist'ovania.

Ako vyplýva zo zistení prieskumu To dá rozum (2019), detí a žiakov s osobitnými potrebami výchovy a vzdelávania u nás neustále pribúda a pribúdat' bude. No aj napriek tomuto poznaniu nemáme na Slovensku vypracovaný systematický model vzdelávania budúcich učitel'ov pre inkluzívne vzdelávanie. Jediné $\mathrm{s}$ čim sa $\mathrm{v}$ tomto duchu stretávame, sú navrhované opatrenia vzdelávania budúcich učitel'ov v dokumente „Učiace sa Slovensko“, v ktorom sa uvádza: „Študentom učitel'stva sa musí dostávat' viac poučenia o tom, ako pracovat's mimoriadne nadanými žiakmi, ako so žiakmi so špeciálnymi výchovno-vzdelávacími potrebami. “ (2017, s. 116) Zmenou môže byt' blížiaca sa akreditácia vysokých škôl. V novom opise profilu absolventa študijného odboru učitel'stvo je už požiadavka prípravy pre inkluzívne vzdelávanie zakomponovaná. 


\section{Záver}

Faktom je, že žiakov so ŠVVP v našich školách pribúda. Podiel žiakov so špecifickými potrebami v základných školách je na Slovensku štvrtý najvyšší v Európe a za posledných 10 rokov narástol o viac ako tretinu. Môže to súvisiet' so spresňujúcou sa diagnostikou, nárokmi kladenými na deti, žiakov, ale aj so súčasným nastavením financovania školstva. (To dá rozum, 2019) V praxi sa dost' často stretávame s dopytom po akejsi „kuchárskej knihe“, t.j. súboru návodov, ako riešit’ a vyriešit’ situácie pred katedrou. Ten kto sa zaoberá výchovou a vzdelávaním vie, že každý žiak je iný, každá škola, situácia je iná a aj samotný učitel' má svoje špecifiká. A síce štúdium na vysokej škole nedokáže a ani nemôže pripravit' budúceho učitel'a na $100 \%$ do samotnej pedagogickej praxe, môže však kvalitnými vyučovacími predmetmi a optimálnym modelom výučby prispiet' už počas štúdia k priblíženiu a zreálneniu pedagogickej reality. Je žiaduce a až nevyhnutné, aby samotní vysokoškolskí učitelia venovali väčšiu pozornost' tvorbe informačných listov predmetov. Ich spracovanie podl'a presne predpísaných požiadaviek je dôležitým podkladom pre samotné vystavanie priebehu vyučovania $\mathrm{v}$ danom období, tiež sú aj prostriedkom kontroly dosiahnutých vedomostí, zručností, kompetencií u samotných študentov.

Príspevok je priebežným výstupom riešenia projektu KEGA č. 046UMB4/2018 "Ako rozumieme inkluzívnej edukácii? Tvorba optimálneho výučbového modelu."

\section{Bibliographic references}

AKREDITACNA KOMISIA. Kritériá akreditácie študijných programov vysokoškolského vzdelávania. Available online: http://www.minedu.sk/data/files/2545.pdf.

ANALYZA ZISTENI O STAVE SKOLSTVA NA SLOVENSKU. Individualizovaná podpora učiacich sa. Available Online: https://analyza.todarozum.sk/docs/19070214420001bsb1/

BAJTOS, J. 2013. Didaktika vysokej školy. Bratislava: Iura Edition. ISBN 978-8080-786-526

BANSAL, S. 2016. Teacher Education Programmes Preparing Teachers for Inclusive Classrooms: A North India Context. Available online: https://pdfs.semanticscholar.org/9d05/029d6b98730289f129327ad5d8b970a6 $4 d 2 c . p d f$.

BELKOVA, V. - ZOLYOMIOVA, P. 2015. Príprava budúcich učitel'ov na inkluzívne vzdelávanie na Katedre pedagogiky PF UMB za posledných 20 rokov. In Dilemy inkluzíveho procesu vedukácii so zameraním na socializáciu osôb so špeciálnymi potrebami. Zborník príspevkov z medzinárodnej vedeckej multiodborovej konferencie, pp. 96-104 Available online.:http://ksp.pf.unipo.sk/data/fckeditor/zborniky/2015_PT_HREBENAR OVA_ZBORNIK.pdf.

BOYLE, Ch. 2017. Australian Pre-service Teacher Attitudes to inclusive education. 
https://www.researchgate.net/publication/319464612_Australian_Preservice_ Teacher_Attitudes_to_inclusive_education

CAVALCANTE DE ANDRADE LOUZADA, C. - MOSCA GIROTO, C. R. 2015. Teacher training according to the perspective of inclusive education in Brazil. Available online: https://www.researchgate.net/publication/291361573_Teacher_training_acco rding_to_the_perspective_of_inclusive_education_in_Brazil.

EUROPEAN AGENCY FOR SPECIAL NEEDS AND INCLUSIVE EDUCATION. Available online: https://www.european-agency.org/countryinformation/slovakia.

EUROPSKA AGENTÚRA PRE ROZVOJ ŠPECIÁLNEHO A
INKLUZIVNEHO VZDELAVANIA. Available online: https://www.minedu.sk/europska-agentura-pre-rozvoj-specialneho-ainkluzivneho-vzdelavania/.

KALEJA, M. - ZEZULKOVA, E. 2018. Preparedness of Czech Primary School Teachers for Inclusive Primary Education. Available online: https://www.researchgate.net/publication/313878707_Preparedness_of_Czec h_Primary_School_Teachers_for_Inclusive_Primary_Education.

KOHNOVA, J. 2003. Současný stav a nový model dalšího vzdělávání učitelů. In Pedagogická orientace. č. 1, (pp. 53-58). Available online: https://journals.muni.cz/pedor/article/viewFile/6708/6188

KOSTURKOVA, M.: Obsahová analýza doktorandského študijného odboru 1.1.4 Pedagogika. Available online: https://www.pulib.sk/web/kniznica/elpub/dokument/Lukacova1/subor/Kostsu rkova.pdf

LOPEZ TORRIJP, M. - MENGUAL-ANDRES, S. 2015. An Attack on Inclusive Education in Secondary Education. Limitations in Initial Teacher Training in Spain. Available online: https://core.ac.uk/download/pdf/71054555.pdf.

NÁRODNÝ PROGRAM ROZVOJA VÝCHOVY A VZDELÁVANIE UČIACE SA SLOVENSKO. 2017. Bratislava, Available online: http://www.minedu.sk/data/files/6987_uciace_sa_slovensko.pdf

PEEBLES, J.L. 2014. Preparing Teachers for Inclusive Classrooms: Introducing the Individual Direct Experience Approach. Available online: https://www.researchgate.net/publication/312892459_Preparing_Teachers_fo r_Inclusive_Classrooms_Introducing_the_Individual_Direct_Experience_Ap proach

POLAKOVA, E. - SPALOVA, L. 2017. Príprava učitel'ov zameraná na riešenie problémov v multikultúrnom školskom prostredí. . In Edukácia Vedecko-odborný časopis. vol. 2, n. 1, pp. 222-227. Available online: https://www.upjs.sk/public/media/15903/Edukacia_1_17.pdf

PORTÁL VŠ, Učitel'stvo akademických predmetov. Available online: https://www.portalvs.sk/sk/studijne-odbory/zobrazit/10101\#details-title_mgr POKYN MINISTRA č. 39/2017, ktorým sa vydávajú profesijné štandardy pre jednotlivé kategórie a podkategórie pedagogických zamestnancov a odborných zamestnancov škôl a školských zariadení. Available online: https://www.minedu.sk/pokyn-ministra-c-392017-ktorym-sa-vydavajuprofesijne-standardy-pre-jednotlive-kategorie-a-podkategorie- 
pedagogickych-zamestnancov-a-odbornych-zamestnancov-skol-a-skolskychzariadeni/

ROGERS-ADKINSON, D. - FRIDLEY, D. 2016. Preparing Teachers for Inclusive Education. Available online: https://www.researchgate.net/publication/309451310_Preparing_Teachers_fo r_Inclusive_Education.

TUREK, I. 2008. Didaktika. Bratislava: Iura Edition. ISBN 978-80-8078198-9.

UNESCO (Policy Guidelines on the Inclusion in Education, 2009). Available online: https://unesdoc.unesco.org/ark:/48223/pf0000177849.

VYHLASKA č. 123/2019 Z.z. Ministerstva školstva, vedy, výskumu a športu Slovenskej republiky z 12. apríla 2019, ktorou sa mení a doplńna vyhláška Ministerstva školstva Slovenskej republiky č. 614/2002Z.z. o kreditovom systéme štúdia v znení vyhlášky č. 155/2013Z.z. Available online: https://www.slov-lex.sk/pravne-

predpisy/SK/ZZ/2019/123/vyhlasene_znenie.html

VYHLASKA č. 244/2019 Z.z. o sústave študijných odborov Slovenskej republiky. Available online: https://www.zakonypreludi.sk/zz/2019-244

VYMEDZENIE JADRA VEDOMOSTI 1. stupňa VŠ štúdia. Available online: https://www.portalvs.sk/sk/studijne-odbory/zobrazit/10101\#detailstitle_bc 2019-04-10.

VYMEDZENIE JADRA VEDOMOSTÍ 2. stupňa VŠ štúdia. Available online: https://www.portalvs.sk/sk/studijne-odbory/zobrazit/10101\#detailstitle_mgr 2019-04-10.

YARULLIN, F. I. - NASUBILLOV, R. R. 2018. Service teachers' preparedness for inclusive education. Available online: https://files.eric.ed.gov/fulltext/EJ1060341.pdf.

ZÁKON č. 138/2019 Z.z. o pedagogických zamestnancoch a o zmene a doplnení niektorých zákonov. Available online: https://www.zakonypreludi.sk/zz/2009-317.

PhDr. Zuzana Osvaldová, PhD.

Faculty of education

PF Universite of Matej Bel

Ružová 13

97411 Banská Bystrica

Slovakia

zuzana.osvaldova@umb.sk

PaedDr. Veronika Vrabcová

Faculty of education

PF Universite of Matej Bel

Ružová 13

97411 Banská Bystrica

Slovakia

veronika.vrabcova@umb.sk 